\title{
PARTIAL PROTECTION FROM ORGANOPHOSPHATE-INDUCED CHOLINESTERASE INHIBITION BY METYRAPONE TREATMENT
}

\author{
RADOSŁAW ŚWIERCZ1 ${ }^{1}$ PIOTR LUTZ'1, SŁAWOMIR GRALEWICZ1 ${ }^{1}$ ZOFIA GRZELIŃSKA ${ }^{1}$, \\ JOANNA PIASECKA-ZELGA ${ }^{2}$, and WOJCIECH WĄSOWICZ ${ }^{1}$
}

\author{
${ }^{1}$ Nofer Institute of Occupational Medicine, Łódź, Poland \\ Department of Toxicology and Carcinogenesis \\ ${ }^{2}$ Nofer Institute of Occupational Medicine, Łódź, Poland \\ Laboratory for Testing Pharmaceuticals and Veterinary Products, GMP Quality System
}

\begin{abstract}
Background: Organophosphates are cholinesterase $(\mathrm{ChE})$ inhibitors with worldwide use as insecticides. Stress response, evidenced by a dramatic and relatively long-lasting (several hours) rise in the plasma glucocorticoid concentration is an integral element of the organophosphate (OP) poisoning symptomatology. In rodents, corticosterone (CORT) is the main glucocorticoid. There are several reports suggesting a relationship between the stressor-induced rise in CORT concentration (the CORT response) and the activity of the cerebral and peripheral $\mathrm{ChE}$. Thus, it seems reasonable to presume that, in OP intoxication, the rise in plasma CORT concentration may somehow affect the magnitude of the OP-induced ChE inhibition. Metyrapone (MET) [2-methyl-1,2-di(pyridin-3-yl)propan-1-one] blocks CORT synthesis by inhibiting steroid 11ß-hydroxylase, thereby preventing the CORT response. Chlorfenvinphos (CVP) [2-chloro-1-(2,4-dichlorophenyl) ethenyl diethyl phosphate] is an organophosphate insecticide still in use in some countries. Material and Methods: The purpose of the present work was to compare the CVP-induced effects - the rise of the plasma CORT concentration and the reduction in ChE activity - in MET-treated and MET-untreated rats. Chlorfenvinphos was administered once at 0.0, 0.5, 1.0 and $3.0 \mathrm{mg} / \mathrm{kg}$ i.p. Metyrapone, at $100 \mathrm{mg} / \mathrm{kg}$ i.p., was administered five times, at 24-h intervals. The first MET dose was given two hours before CVP. Conclusion: The following was observed in the MET-treated rats: i) no rise in plasma CORT concentration after the CVP administration, ii) a reduced inhibition and a faster restitution of blood and brain ChE activities. The results suggest that MET treatment may confer significant protection against at least some effects of OP poisoning. The likely mechanism of the protective MET action has been discussed.
\end{abstract}

Key words:

Chlorfenvinphos, Metyrapone, Cholinesterase, Corticosterone

\section{INTRODUCTION}

The organophosphate (OP) compounds are one of the most common pesticides. Their high toxicity combined with the mode of use and easy accessibility result in a high number of intoxications, especially in developing countries [1-3]. Numerous human studies have shown that acute as well as repeated exposures to OP may produce long-lasting health consequences [4,5]. The basic mechanism of the OP toxic action - in target as well nontarget organisms, including man - consists in inhibition of acetylcholinesterase (AChE), an enzyme decomposing acetylcholine (ACh). Consequently, excessive ACh supply and

Received: October 3, 2012. Accepted: July 23, 2013.

Corresponding author: R. Świercz, Department of Toxicology and Carcinogenesis, Nofer Institute of Occupational Medicine, św. Teresy 8, 91-348-Łódź, Poland (e-mail: radek@imp.lodz.pl). 
the resulting overstimulation of cholinergically innervated brain structures and peripheral effectors is regarded as the primary cause of the acute toxicity as well as the long-term effects of the OP exposure [6,7]. Functional imbalance in neurotransmitter systems triggers adaptive mechanisms. The well known adaptation to OP intoxication consists in down-regulation of cholinergic receptors [8,9]. Another one is the activation of $\mathrm{AChE}$ synthesis [10,11]. Those adaptive responses restore the balance in the cholinergic transmission.

A consistent symptom in OP intoxication is a strong activation of the hypothalamo-pituitary-adrenal (HPA) axis which is evidenced by a manifold and relatively longlasting (up to ten or more hours) increase in the blood glucocorticoid concentration [12,13]. Treatment with atropine, a muscarinic antagonist, prevents this effect, thus suggesting that it may be related to the cholinergic overstimulation $[14,15]$. The rise in glucocorticoid concentration in OP intoxication deserves attention for several reasons. First, it confirms that OPs are powerful chemical stressors. Second, it is known that overproduction of glucocorticoids may result in morphological and functional changes in some brain structures $[16,17]$ which allows one to suspect its relationship with at least some of the known long-lasting effects of OP exposure. And third, it is likely that glucocorticoids may somehow influence the adaptations related with the ChE activities. The main glucocorticoid in rodents is corticosterone (CORT). Blood CORT concentration rises after exposure to stressors. Numerous animal studies revealed marked changes in AChE activity, mainly in brain, after exposure to various nonchemical stressors. In some cases, however, the observed changes consisted in an increase [11,18-21], whereas in others in a decrease [22-24] of AChE activity. No changes were observed in adrenalectomized animals [18,20,25]. Treatment with CORT also results in changes in AChE activity [20,26,27], which suggests that the changes observed in stressed animals were due to the CORT response, i.e. the stressor-induced rise of the CORT release from adrenals. An involvement of glucocorticoids in the control of AChE activity is also suggested by some in vitro studies; they showed a marked stimulation of AChE synthesis in P12 cells treated for $6 \mathrm{~h}$ with CORT [28]. The observations cited above allow one to presume that in the OP intoxication the magnitude and the dynamics of the AChE response may be somehow affected by the CORT response. The existing observations concerning this issue are scarce and inconsistent; some report no effect of adrenalectomy (i.e. a surgical blockade of CORT synthesis) on the level of the OP-induced AChE inhibition [15,25] whereas in others a slowing of the rate of AChE restitution was noted [29].

The purpose of the present experiment was to find out whether and in what way blocking the CORT response affects the level of inhibition and the restitution rate of ChE activity in blood (plasma and erythrocytes) and brain of rats intoxicated with an OP insecticide. The insecticide used was chlorfenvinphos [2-Chloro-1-(2,4dichlorophenyl) ethenyl] diethyl phosphate)] - CVP, a compound used in our earlier studies. Chlorfenvinphos is a direct ChE inhibitor [30] and efficient inducer of the CORT response [13,31]. Metyrapone \{[2-methyl-1,2-di(pyridin-3-yl)propan-1-one] - MET\} was used for blocking the CORT response. Metyrapone blocks the CORT synthesis by inhibiting steroid $11 \beta$-hydroxylase [32].

\section{MATERIALS AND METHODS}

\begin{abstract}
Animals
Adult male Wistar rats (325-340 g), outbreds, from our Institute's own breeding facility were used. Two weeks before the experiment onset they were transferred to the experimental facility where they were housed in polypropylene rat cages, one animal per cage. The temperature $\left(22^{\circ} \mathrm{C}\right)$, humidity (50-60\%) and the light/dark cycle (12/12 h with
\end{abstract}


Table 1. Experimental groups and treatment

\begin{tabular}{lccc}
\hline & $\begin{array}{c}\text { Animals treated } \\
(\mathrm{n})\end{array}$ & $\begin{array}{c}\text { Dose } \\
(\mathrm{mg} \mathrm{CVP} / \mathrm{kg} \mathrm{b.w.})\end{array}$ & Cotreatment \\
\hline $\mathrm{SAL} / 0.0$ & 20 & $0.0(\mathrm{oil})$ & $5 \times$ saline \\
$\mathrm{SAL} / 0.5$ & 20 & 0.5 & $5 \times$ saline \\
$\mathrm{SAL} / 1.0$ & 20 & 1.0 & $5 \times$ saline \\
$\mathrm{SAL} / 3.0$ & 20 & 3.0 & $5 \times$ saline \\
$\mathrm{MET} / 0.0$ & 20 & $0.0(\mathrm{oil})$ & $5 \times \mathrm{MET}$ \\
$\mathrm{MET} / 0.5$ & 20 & 0.5 & $5 \times \mathrm{MET}$ \\
$\mathrm{MET} / 1.0$ & 20 & 1.0 & $5 \times \mathrm{MET}$ \\
$\mathrm{MET} / 3.0$ & 20 & 3.0 & $5 \times \mathrm{MET}$ \\
\hline
\end{tabular}

light on from 6:00 a.m. to 6:00 p.m.) were controlled automatically. The cages and cage bedding (hardwood shavings) were changed twice a week. Food (Murigran pellets from AGROPOL, Motycz, Poland) and tap water were accessible ad libitum. Body weight was measured routinely once a week. At the beginning of the experiment the animals were divided into eight groups, 20 in each group (Table 1).

All animal use procedures were approved by the local Bioethical Committee (Medical University of Lodz, Poland, Decision No. 33/LB370/2007).

\section{Chemicals and administration procedures}

Chlorfenvinphos $\{[2-C h l o r o-1-(2,4-$ dichlorophenyl)ethenyl] diethyl phosphate - CVP\}, technical grade, was obtained from the manufacturer (ORGANIKA-AZOT, Jaworzno, Poland). Metyrapone \{[2-methyl-1,2-di(pyridin3-yl)propan-1-one]-MET\} was purchased from SIGMA. In order to obtain the required concentrations, CVP was diluted with olive oil and MET was dissolved in physiological saline (SAL). Both substances were administered intraperitoneally at $1.0 \mathrm{ml} / \mathrm{kg}$ b.w.

Chlorfenvinphos was administered once at doses of 0.0 (pure olive oil), $0.5,1.0$ or $3.0 \mathrm{mg} / \mathrm{kg}$ b.w. Metyrapone at daily doses of $100 \mathrm{mg} / \mathrm{kg}$ b.w., or SAL, were administered five times. The first MET injection was performed $2 \mathrm{~h}$ before the CVP injection and was repeated during the following four days at approximately the same hour (between 8:00 and 9:00 a.m.). The CVP doses were selected on the basis of data from our earlier studies on the same compound [14]. The daily MET dose was established on the basis of published reports [33,34], as well as our own unpublished observations.

\section{Biochemical analyses}

The animals (four per each time point) were killed by decapitation at selected time intervals, i.e. 3 h, 24 h, 7 days, 14 days and 21 days after the CVP administration. (In our earlier studies we have found that at the $3.0 \mathrm{mg} / \mathrm{kg}$ b.w CVP i.p. maximum ChE inhibition occurs about $3 \mathrm{~h}$ after the administration and the enzyme activity returns to normal level within about three weeks time [12]. The arteriovenous blood $5 \mathrm{ml}$ samples were collected into Vacutainers containing an anticoagulant ( $\mathrm{K}_{2}$ EDTA, $\left.10.8 \mathrm{mg}\right)$. After centrifuging $(10 \mathrm{~min}, 1780 \times \mathrm{g})$, the plasma was transferred to Eppendorf vials and stored at $-20^{\circ} \mathrm{C}$ until analysis. Erythrocyte $0.1 \mathrm{ml}$ samples were mixed with $3.9 \mathrm{ml}$ of distilled water and stored at $-20^{\circ} \mathrm{C}$ until analysis.

The brains were removed from skulls as quickly as possible, chilled in ice-cold physiological saline and stored at $-20^{\circ} \mathrm{C}$ until analysis. 


\section{Serum corticosterone assays}

Concentration of corticosterone in plasma was estimated by the use of high performance liquid chromatography (HPLC) using betamethasone as an internal standard [35].

\section{Cholinesterase activity determination}

Cholinesterase activity in blood, plasma and erythrocytes, as well as in the brain was assayed with the modified Ellman's method using the Acetylcholinesterase Multi Reagent 96 Well Kit, Cat. No. 1418-500-K, IKZUS ENVIRONMENT, according to the manufacturer's protocol. (Please note that this method is not selective for AChE. Acetylcholinesterase is the only cholinesterase present in erythrocytes. However, in the rat and other rodents, two cholinesterases which can be targeted by an OP, AChE and butyrylcholinesterase $(\mathrm{BuChE})$, both are present in plasma and in the brain [36]. Therefore, the use of the term: "cholinesterase - ChE", was preferred in the present work). Enzyme activity was determined be the use of the Multiskan Ascent Thermo Labsystems spectrophotometer for microplates and the data was recalculated using the equations specified in the manual.

\section{Statistics}

Differences were assessed using the Kruskall-Wallis test in Dunn's modification [37]. The trend analysis was performed be the use of Jonckheere's test [38]. The differences were regarded as significant when the probability of the null hypothesis was $<0.05$.

\section{RESULTS}

A comparison of the CVP effect on the blood CORT concentration in MET-treated and MET-untreated rats is shown in Figure 1. In MET-untreated rats, administration of CVP resulted, $3 \mathrm{~h}$ after the pesticide administration, in a dose-related rise in plasma CORT concentration (Jonckheer's trend test, $\mathrm{p}_{\mathrm{j}}<0.005$ ). In rats receiving

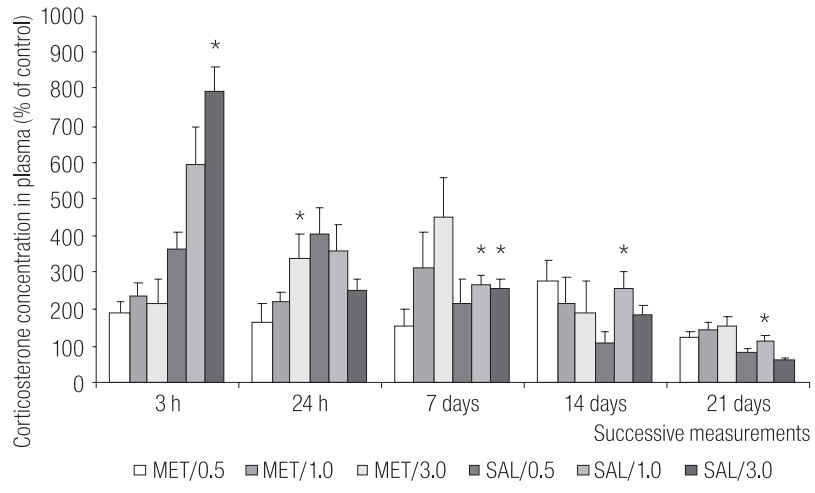

$* \mathrm{p}<0.05$ compared to control.

Metyrapone at doses of $100 \mathrm{mg} / \mathrm{kg}$ i.p. was administered 5 times at $24 \mathrm{~h}$ intervals; the first metyrapone dose was given $2 \mathrm{~h}$ before the CVP administration. Data (means \pm SEM, $N=4-5$ ) are presented as percent of the values measured at the same time points in the respective control groups (SAL/0.0, or MET/0.0).

In the control groups the plasma corticosterone concentration ranged from 12.19 to $29.47 \mathrm{ng} / \mathrm{ml}$.

Fig. 1. Diagrams illustrating changes in the plasma corticosterone concentration following CVP $(0.5,1.0$ or $3.0 \mathrm{mg} / \mathrm{kg}$ i.p.) administration to metyrapone-treated and metyrapone-untreated rats

the highest $(3.0 \mathrm{mg} / \mathrm{kg})$ CVP dose, the rise was almost eight-fold as compared to the control (SAL/0.0) group. Significant increase in plasma CORT concentration was noted on day 7 (CVP dose 1.0 and $3.0 \mathrm{mg} / \mathrm{kg}$ ) and day 14 (CVP dose $1.0 \mathrm{mg} / \mathrm{kg}$ ). In the group which was given the highest CVP dose, the plasma CORT concentration on day 21 was significantly reduced compared to the control. In the MET-treated rats, CVP administration induced no clear-cut changes in plasma CORT concentration; a significant increase was noted solely in the MET/3.0 group and only at the $24 \mathrm{~h}$ time point.

Figures 2, 3 and 4 illustrate the dynamics of the CVP-induced changes in ChE activity in blood (plasma and erythrocytes) and brain of MET-treated and MET-untreated rats. In the MET-untreated rats the CVP administration resulted in a dose-dependent decrease of the ChE activity in all the compartments studied. This effect was most pronounced 3 and $24 \mathrm{~h}$ after the pesticide administration. 


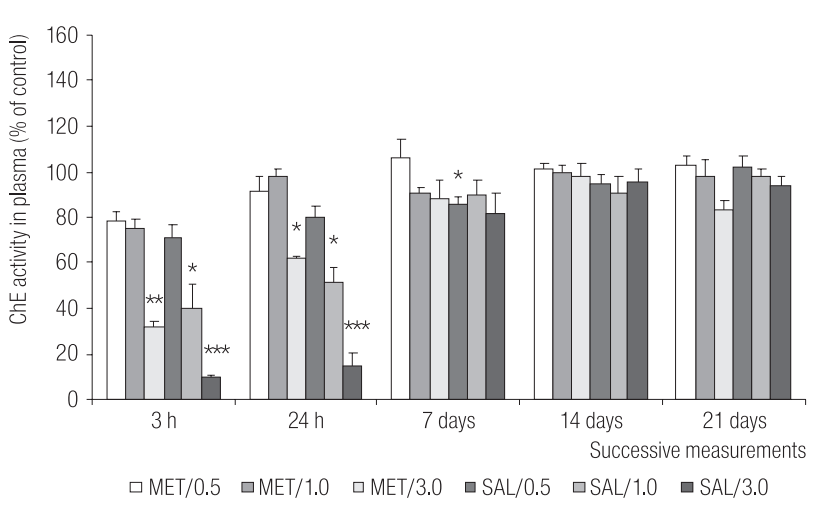

${ }^{*} \mathrm{p}<0.05,{ }^{* *} \mathrm{p}<0.01$, and ${ }^{* * *} \mathrm{p}<0.001$ compared to control.

Remaining description as in Figure 1.

The control values in the plasma $\mathrm{ChE}$ activities ranged $1.02-1.89 \mu \mathrm{mol} / \mathrm{min}$ per $1 \mathrm{ml}$.

Fig. 2. Diagrams illustrating changes in the plasma $\mathrm{ChE}$ activities following CVP $(0.5,1.0$ or $3.0 \mathrm{mg} / \mathrm{kg}$ i.p. $)$ administration to metyrapone-treated and metyraponeuntreated rats

Restitution of the enzyme activity was the fastest in plasma; in all groups it was complete by day 7 , whereas in the erythrocytes and the brain of rats given 1.0 or $3.0 \mathrm{mg} / \mathrm{kg}$, at that time the $\mathrm{ChE}$ activities were still significantly reduced at that time. By day 21, restitution was complete in all compartments.

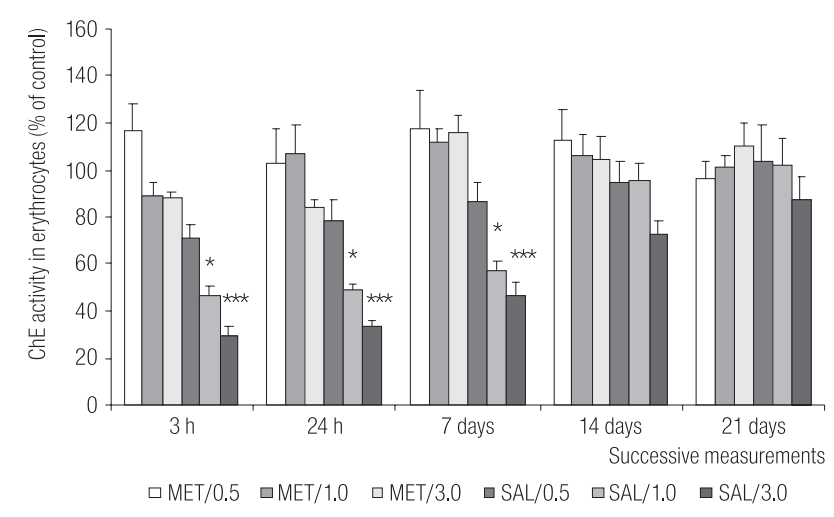

$* \mathrm{p}<0.05$ and ${ }^{* * *} \mathrm{p}<0.001$ compared to control.

Remaining description as in Figure 1.

The control values in the erythrocyte $\mathrm{ChE}$ activities range 14.10-22.40 $\mu \mathrm{mol} / \mathrm{min}$ per $1 \mathrm{ml}$.

Fig. 3. Diagrams illustrating changes in the erythrocyte $\mathrm{ChE}$ activities following CVP $(0.5,1.0$ or $3.0 \mathrm{mg} / \mathrm{kg}$ i.p. $)$ administration to metyrapone-treated and metyraponeuntreated rats

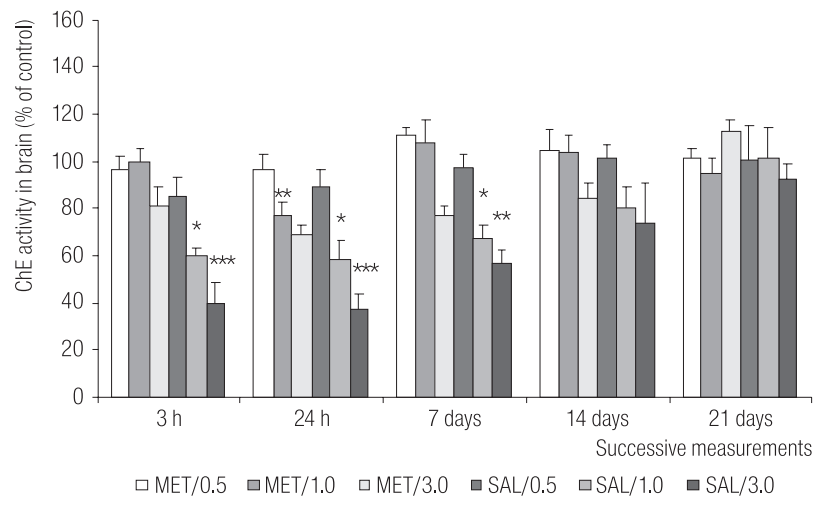

${ }^{*} \mathrm{p}<0.05,{ }^{* *} \mathrm{p}<0.01$ and ${ }^{* * *} \mathrm{p}<0.001$ compared to control.

Remaining description as in Figure 1.

The control values in the brain $\mathrm{ChE}$ activities ranged

$0.17-0.25 \mu \mathrm{mol} / \mathrm{min}$ per $1 \mathrm{mg}$ protein.

Fig. 4. Diagrams illustrating changes in the brain $\mathrm{ChE}$ activity following CVP administration in metyrapone-treated and metyraponeuntreated rats

In the MET-treated rats, CVP administration at the 0.5 or $1.0 \mathrm{mg} / \mathrm{kg}$ dose resulted in no significant alterations in the $\mathrm{ChE}$ activity in any of the compartments tested. In rats given CVP at the $3.0 \mathrm{mg} / \mathrm{kg}$ dose, the plasma $\mathrm{ChE}$ activity was significantly reduced at 3 and $24 \mathrm{~h}$, and that of the brain $\mathrm{ChE}$ at $24 \mathrm{~h}$ after the pesticide administration. In both those compartments, however, the reduction was less pronounced than that noted in the MET-untreated rats given the same CVP dose.

\section{DISCUSSION AND CONCLUSIONS}

As expected, the CVP administrations resulted in:

- a decrease in the ChE activities in blood and in the brain; in all studied compartments, the magnitude of this effect was positively correlated with the CVP dose; the decrease was most pronounced in plasma but, generally, the differences between compartments were not great; the enzyme activity returned to normal within several days at a rate correlated with the dose (faster at lower doses) and the compartment (faster in case of plasma);

- an increase in the serum CORT concentration, i.e. the CORT response. 
Also in this case the magnitude of this effect was positively correlated with the CVP dose. It disappeared within $24 \mathrm{~h}$. (The intervals between successive measurements did not enable a more precise assessment of the duration of the CORT response in the present study).

Both effects reported above are characteristic for the majority of OPs, including CVP [13,31] and require no discussion. The most important issue is the effect of MET. The results show that the treatment resulted in reduction of the CVP-induced CORT response, markedly weaker ChE inhibition and accelerated recovery of the enzyme activity in all studied compartments. It is worth noting, however, that in the case of the plasma ChE the protective effect of the MET treatment was weaker, especially in the MET/3.0 group vs. remaining compartments. The most likely source of this difference may be the large contribution of $\mathrm{BuChE}$ to the plasma $\mathrm{ChE}$ activity; $\mathrm{BuChE}$ is known to be inhibited more effectively by most OPs than AChE [39].

MET is a known inhibitor of the CORT synthesis $[32,40]$. Therefore, the absence of the CORT response in the METtreated rats of the present study was the expected outcome. A number of published works allowed one to predict that a blockade of the CORT synthesis might somehow modify the CVP effect: the magnitude of the ChE inhibition and/or the rate of the restitution of the enzyme activity. They do not allow, however, to predict the trend of the expected change. A transient rise in blood CORT concentration is a known response to various stressors. However, exposure to stressors results also in changes in $\mathrm{ChE}$ activities and an involvement of CORT in this effect seems quite likely. Kaufer et al. [10,11] for example, observed increased AChE synthesis in the neocortex and hippocampus after exposure to a physical stressor or an OP exposure. Increased AChE activity after exposure to stressors was also reported by other authors [18-21,41-44]. An involvement of CORT in these effects is suggested by some in vitro observations on PC 12 cells which showed an increase in AChE catalytical activity and AChE RNA synthesis after incubation with CORT [28]. Based on the above observations, one might expect an amplification of the OP-induced ChE inhibition and/or slowing down the rate of restitution of the activity in the MET treated animals. An effect of this kind, i.e. "... decreased rate of regeneration of brain and striate muscle acetylcholinesterase..." was noted in adrenalectomized mice after sublethal poisoning with diisopropylphosphofluoridate (DFP) [29]. In the present study the effect of MET treatment, i.e. the compromised $\mathrm{ChE}$ inhibition and the accelerated restitution, was apparently opposite to that cited above, thus raising the question whether it could be due to a METinduced inhibition of the CORT synthesis. Some authors reported a reduction in AChE activity after stress [22-24,44]. Similar effect was observed in striate muscles of animals treated with CORT $[26,45]$ or dexamethasone, a syntetic glucocorticoid [27]. These observations suggest that an excess of glucocorticoids might downregulate, directly or indirectly, the $\mathrm{ChE}$ activity. If so, then in the case of the OP poisoning, the induced CORT response might somehow amplify the effect of the pesticide, i.e. the reduction in ChE activity. In such a case, the weaker reduction in ChE activity in MET-treated rats after CVP exposure could be explained as a result of the absence of the CORT response (i.e. the transient excess of glucocorticoids).

The above conjecture may be confirmed by administering CVP to adrenalectomized and CORT-supplemented rats. At present we are not in possession of our own data from an experiment like that. However, some speculations based on several published reports seem to be reasonable. It has been shown, for example, that adrenalectomized animals (rats) do not differ from controls (unoperated or sham operated) with regard to $\mathrm{AChE}$ inhibition after an OP exposure [15,25]. Moreover, it has been found that atropine pretreatment in soman-intoxicated rats prevented the CORT response but had no effect on the level of $\mathrm{AChE}$ inhibition $[14,15]$. The above observations suggest that in case of an OP intoxication, unlike in case of exposure to 
nonchemical stressors, there is no relationship between the CORT response and the AChE activity. If so, the MET effects observed in the present experiment do not seem to be attributable to inhibition of the CORT synthesis.

A search through the literature reveals that results similar to these obtained in the present study, i.e. a decrease of the inhibitory effect of OP on ChE activity, were achieved with the use (as prophylaxis or therapy) of memantine [46-48], $\mathrm{N}$-acetylcysteine (NAC) [49-51], or caffeic acid [52]. NAC and caffeic acids are known antioxidants. The biochemical alterations produced by memantine (a noncompetitive inhibitor of the NMDA receptors) also suggest a protective action against the generation of oxidative stress, i.e. overproduction of reactive oxygen or nitrogen species in the brain and peripheral tissues [48].

Oxidative stress is regarded as one of the main adverse effects of OP intoxication [53]. According to some authors, oxidative stress is responsible for the long-term degenerative alterations in the nervous system which may follow an OP exposure [48,54]. Ample evidence shows that in condition of oxidative stress the activity of cholinesterases is inhibited and that the excess of hydrogen peroxide is the main culprit [55-58]. It follows from the above that two factors determine the reduction in cholinesterase activities in OP intoxication: first is the inactivation due to the OP-ChE binding and the second, which results from the former, the oxidative stress. This explains why treatment with antioxidants may result in reduction of the $\mathrm{ChE}$ inhibition induced by an OP exposure. It seems quite probable that in the present experiment we were dealing with a similar process, that is a reduction of the OP-induced oxidative stress. It is generally recognised that MET acts not only to inhibit $11 \beta$-hydroxylase, but also other enzymes of the cytochrome P450 system [32,59]. This system plays a key role in the metabolism of numerous xenobiotics. Its activity, however, is the main source of reactive oxygen species in at least some mammalian tissues $[60,61]$. Thus, inhibition of the P450 system may prevent generation of oxidative stress.
Exposure to CVP, like exposure to other OP insecticides, results in generation of reactive oxygen metabolites and oxidative stress $[62,63]$. It is also known that cytochrome P450 participates in the CVP metabolism [64,65] and it is likely that the P450 activity is an important cause of the CVP-induced oxidative stress. Thus, inhibition of the P450 system by MET limits the oxidative stress generation and, owing to that, protects, albeit partially, $\mathrm{ChE}$ from inhibition. However, on the other hand, inhibition of the $\mathrm{P} 450$ system may result in slowing down the CVP metabolism, what should increase rather than decrease its toxicity. Keeping this in mind, the MET effect observed in the present work might suggest that the benefits from the reduction of the oxidative stress, assessed on the basis of the reduction in $\mathrm{ChE}$ activity, are greater than the losses resulting from slowing down the CVP metabolism.

\section{ACKNOWLEDGEMENTS}

This research was supported under the statutory activities of the Nofer Insitute of Occupational Medicine IMP grant 1.6. The authors are grateful to Krzysztof Mader for his excellent technical assistance and to Mr Stefan Markiewicz correcting the English grammar and style of the manuscript.

\section{REFERENSES}

1. Ecobichon DJ, Davies JE, Doul J, Ehrlich M, Joy R, McMillan D, et al. Neurotoxic effects of pesticides. In: Wilkinson CF, Baker SR, editors. The effect of pesticides on human health. Princeton, NJ: Princeton Scientific; 1990. p. 131-99.

2. Finkelstein Y, Milatovic D, Lazarovici P, Ophir A, Richter ED, Aschner M, et al. Peaceful use of disastrous neurotoxicants. Neurotoxicology. 2010;31:608-20, http://dx.doi. org/10.1016/ j.neuro.2010.06.009.

3. Jeyratnam J. Acute pesticide poisoning: A major global health problem. World Health Stat Q. 1990;43:139-44.

4. Jamal GA. Neurological syndromes of organophosphorus compounds. Adverse Drug React Toxicol Rev. 1997;16:133-70. 
5. Jamal GA, Hansen S, Julu PO. Low level exposures to organophosphorus esters may cause neurotoxicity. Toxicology. 2002;181-2:23-33, http://dx.doi.org/10.1016/S0300-483X(02) 00447-X.

6. Costa LG. Current issues in organophosphate toxicology. Clin Chim Acta. 2006;366:1-13, http://dx.doi.org/10.1016/ j.cca.2005.10.008.

7. Weinbroum AA. Pathophysiological and clinical aspects of combat anticholinesterase poisoning. $\mathrm{Br}$ Med Bull. 2005;72:119-33, http://dx.doi.org/10.1093/bmb/ldh038.

8. Fitzgerald BB, Costa LG. Modulation of muscarinic receptors and acetylcholinesterase activity in lymphocytes and in brain areas following repeated organophosphate exposure in rats. Fundam Appl Toxicol. 1993;20:210-6, http://dx.doi. org/10.1006/faat.1993.1028.

9. Kobayashi H, Suzuki T, Sakamoto M, Hashimoto W, Kashiwada K, Sato I, et al. Brain regional acetylcholinesterase activity and muscarinic acetylcholine receptors in rats after repeated administration of cholinesterase inhibitors and its withdrawal. Toxicol Appl Pharmacol. 2007;219:151-61, http://dx.doi.org/10.1016/ j.taap.2006.11.006.

10. Kaufer D, Friedman A, Seidman S, Soreq H. Acute stress facilitates long-lasting gene expression. Nature. 1998;393: 373-7, http://dx.doi.org/10.1038/30741.

11. Kaufer D, Friedman A, Seidman S, Soreq H. Anticholinesterases induce multigenic transcriptional feedback response suppressing cholinergic neurotransmission. Chem Biol Interact. 1999;119-20:349-60, http://dx.doi.org/10.1016/S00092797(99)00046-0.

12. Gralewicz S, Soćko R. Persisting behavioural and electroencephalographic effects of exposure to chlorphenvinphos, an organophosphorous pesticide, in laboratory animals. Int J Occup Med Environ Health. 1997;10:375-94.

13. Osicka-Koprowska A, Lipska M, Wysocka-Paruszewska B. Effects of chlorfenvinphos on plasma corticosterone and aldosterone levels in rats. Arch Toxicol. 1984;55:68-9, http:// dx.doi.org/10.1007/BF00316589.
14. Kassa J, Bajgar J. Treatment of the stressogenic effect of dichlorvos. Sb Ved Pr Lek Fak Karlovy Univerzity Hradci Kralove. 1994;37:29-32.

15. Smallridge RC, Carr FE, Fein HG. Diisopropylfluorophosphate (DFP) reduces serum prolactin, thyrotropin, luteinizing hormone, and growth hormone and increases adrenocorticotropin and corticosterone in rats: Involvement of dopaminergic and somatostatinergic as well as cholinergic pathways. Toxicol Appl Pharmacol. 1991;108:284-95, http:// dx.doi.org/10.1016/0041-008X(91)90118-X.

16. McEwen BS. Effects of adverse experiences for brain structure and function. Biol Psychiatry. 2000;48:721-31, http:// dx.doi.org/10.1016/S0006-3223(00)00964-1.

17. Sato H, Takahashi T, Sumitani K, Takatsu H, Urano S. Glucocorticoid generates ROS to induce oxidative injury in the hippocampus, leading to impairment of cognitive function in rats. J Clin Biochem Nutr. 2010;47:224-32, http://dx.doi. org/10.3164/jcbn.10-58.

18. Naik SR, Gokhale SV, Sheth UK. Effect of stress, adrenalectomy and steroids on brain cholinesterase. Indian J Med Res. 1975;63:695-700.

19. Naik SR, Kelkar MR, Sheth UK. Effect of chronic stress on brain cholinesterase. Indian J Med Res. 1977;66:513-6.

20. Sembulingham K, Sembulingham P, Namasivayam A. Effect of acute noise stress on acetylcholinesterase activity in discrete areas of the rat brain. Indian J Med Sci. 2003;57: 487-92.

21. Tsakiris S, Kostopoulos AN. Time changes in $\mathrm{Na}^{+}, \mathrm{K}(+)$ ATPase, $\operatorname{Mg}(++)$-ATPase, and acetylcholinesterase activities in the rat cerebrum and cerebellum caused by stress. Pharmacol Biochem Behav. 1993;44:339-42, http://dx.doi. org/10.1016/0091-3057(93)90471-5.

22. Das A, Rai D, Dikshit M, Palit G, Nath C. Nature of stress: differential effects on brain acetylcholinesterase activity and memory in rats. Life Sci. 2005;77:2299-311, http://dx.doi. org/10.1016/j.lfs.2005.02.020.

23. Gabriel NN, Soliman KFA. Effects of stress on the acetylcholinesterase activity of the hypothalamus-pituitary-adrenal 
axis in the rat. Horm Res. 1983;17:43-8, http://dx.doi. org/10.1159/000179673.

24. Sunanda Rao BS, Raju TR. Restraint stress-induced alterations in the levels of biogenic amines, amino acids and AChE activity in the hippocampus. Neurochem Res. 2000;25: 154752, http://dx.doi.org/10.1023/A:1026606201069.

25. Matin MA, Sattar S, Husain K. Modification of malathion induced neurochemical changes by adrenalectomy in rats. Mol Chem Neuropathol. 1990;13:119-28, http://dx.doi. org/10.1007/BF03159913.

26. Gibson A, Pollock D. Reduction in the cholinesterase activity of the rat anococcygeus muscle produced by corticosterone. Br J Pharmacol. 1975;55:69-72, http://dx.doi. org/10.1111/j.1476-5381.1975.tb07612.x.

27. Weber U, Brank M, Grubic Z. Glucocorticoids differentially control synthesis of acetylcholinesterase and butyrylcholinesterase in rat liver and brain. Chem Biol Interact. 1999;11920:341-7, http://dx.doi.org/10.1016/S0009-2797(99)00045-9.

28. Meshorer E, Erb C, Gazit R, Pavlovsky L, Kaufer D, Friedman A, et al. Alternative splicing and neuritic mRNA translocation under long-term neuronal hypersensitivity. Science. 2002;295:508-12, http://dx.doi.org/10.1126/scien ce. 1066752 .

29. Ambrus PS, Ambrus LC. Effect of adrenalectomy on the synthesis of cholinesterases. J Med. 1975;6:317-21.

30. Agency for Toxic Substances and Disease Registry (ATSDR). Toxicological profile for chlorfenvinphos. Atlanta, GA: ATSDR, US Department of Health and Human Services; 1997.

31. Gralewicz S, Lutz P, Kur B. Pretreatment with footshock alters some effects of subsequent organophosphate exposure. Neurotoxicology. 2005;26:159-71, http://dx.doi. org/10.1016/j.neuro.2004.12.003.

32. Temple TE, Liddle GW. Inhibitors of adrenal steroid biosynthesis. Annu Rev Pharmacol. 1970;10:199-218, http://dx.doi. org/10.1146/annurev.pa.10.040170.001215.

33. Marinelli M, LeMoal M, Piazza PV. Acute pharmacological blockade of corticosterone secretion reverses food restriction-induced sensitization of the locomotor responses to cocaine. Brain Res. 1996;724:251-5, http:// dx.doi.org/10.1016/0006-8993(96)00309-5.

34. Piazza PV, Marinelli M, Jodogne C, Deroche V, Rougé-Pont $\mathrm{F}$, Maccari $\mathrm{S}$, et al. Inhibition of corticosterone synthesis by metyrapone decreases cocaine-induced locomotion and relapse of cocaine self-administration. Brain Res. 1994;658:259-64, http://dx.doi.org/10.1016/ S0006-8993(09)90034-8.

35. Ling S, Jamali F. Effect of cannulation surgery and restraint stress on the plasma corticosterone concentration in the rat: application of an improved corticosterone HPLC assay. J Pharm Pharm Sci. 2003;6:246-51.

36. Li B, Stribley J, Ticu A, Xie W, Schopfer LM, Hammond $\mathrm{P}$, et al. Abundant tissue butyrylcholinesterase and its possible function in the acetylcholinesterase knockout mice. J Neurochem. 2000;75:1320-31, http://dx.doi.org/10.1046/ j.1471-4159.2000.751320.x.

37. Dunn OJ. Multiple comparison using rank sums. Technometrics. 1964;6:241-52, http://dx.doi.org/10.1080/004017 06.1964.10490181.

38. Jonckheere AR. A distribution-free k-sample test against ordered alternatives. Biometrika. 1954;41:135-45, http://dx. doi.org/10.1093/biomet/41.1-2.133, http://dx.doi.org/10.2307/ 2333011.

39. Lotti M. Cholinesterase inhibition: complexities in interpretation. Clin Chem. 1995;41:1814-8.

40. Jenkins JS, Meakin JW, Nelson DH, Thorn GW. Inhibition of adrenal steroid 11-oxygenation in the dog. Science. 1958;128:47880, http://dx.doi.org/10.1126/science.128.3322.478-a.

41. Appleyard ME, Green AR, Greenfield S. Acetylcholinesterase activity rises in rats cerebrospinal fluid post-ictally; effect of a substantia nigra lesion on this rise and on seizure threshold. Br J Pharmacol. 1987;91:149-54, http://dx.doi. org/10.1111/j.1476-5381.1987.tb08993.x.

42. Fatranska M, Budai D, Oprsalova Z, Kvetnansky R. Acetylcholine and its enzymes in some brain areas of the rat under stress. Brain Res. 1987;424:109-14, http://dx.doi. org/10.1016/0006-8993(87)91198-X. 
43. Romero-Vecchione E, Fatranská M, Kvetnanský R. Acetylcholinesterase activity in several hypothalamic and brain stem nuclei after acute and chronic immobilization stress. Endocrinol Exp. 1987;21:159-65.

44. Cohen O, Reichenberg A, Perry C, Ginzberg D, Pollmächer T, Soreq H, et al. Endotoxin-induced changes in human working and declarative memory associate with cleavage of plasma „readthrough“ acetylcholinesterase. J Mol Neurosci. 2003;21:199-212, http://dx.doi.org/10.1385/JMN:21:3:199.

45. Brank M, Zajc-Kreft K, Kreft S, Komel R, Grubic Z. Biogenesis of acetylcholinesterase is impaired, although its mRNA level remains normal, in the glucocorticoid-treated rat skeletal muscle. Eur J Biochem. 1998;251:374-81, http://dx.doi. org/10.1046/j.1432-1327.1998.2510374.x.

46. Gupta RC, Kadel WL. Methyl parathion acute toxicity: Prophylaxis and therapy with memantine and atropine. Arch Int Pharmacodyn Ther. 1990;305:208-21.

47. Gupta RC, Dettbarn WD. Potential of memantine, D-tubocurarine and atropine in preventing acute toxic myopathy induced by organophosphate nerve agents: Soman, sarin and VX. Neurotoxicology. 1992;13:649-61.

48. Milatovic D, Gupta RC, Aschner M. Anticholinesterase toxicity and oxidative stress. Sci World J. 2006;6:295-310, http:// dx.doi.org/10.1100/tsw.2006.38.

49. Peña-Llopis S, Ferrando MD, Peña JB. Fish tolerance to organophosphate-induced oxidative stress is dependent on the glutathione metabolism and enhanced by $\mathrm{N}$-acetylcysteine. Aquat Toxicol. 2003;65:337-60, http://dx.doi.org/10.1016/ S0166-445X(03)00148-6.

50. Peña-Llopis S, Ferrando MD, Peña JB. Increased recovery of brain acetylcholinesterase activity in dichlorvos-intoxicated European eels Anguilla anguilla by bath treatment with N-acetylcysteine. Dis Aquat Organ. 2003;55:237-45, http://dx.doi.org/10.3354/dao055237.

51. Yurumez Y, Cemek M, Yavuz Y, Birdane YO, Buyukokuroglu ME. Beneficial effect of N-acetylcysteine against organophosphate toxicity in mice. Biol Pharm Bull. 2007;30:490-4, http://dx.doi.org/10.1248/bpb.30.490.
52. Rezg R, Mornagui B, El-Fazaa S, Gharbi N. Caffeic acid attenuates malathion induced metabolic disruption in rat liver, involvement of acetylcholinesterase activity. Toxicology. 2008;250:27-31, http://dx.doi.org/10.1016/j.tox.2008.05.017.

53. Soltaninejad K, Abdollahi M. Current opinion on the science of organophosphate pesticides and toxic stress: A systematic review. Med Sci Monit. 2009;15(3):RA75-90.

54. Zaja-Milatovic S, Gupta R, Aschner M, Milatovic D. Protection of DFP-induced oxidative damage and neurodegeneration by antioxidants and NMDA receptor antagonist. Toxicol Appl Pharmacol. 2009;240:124-31, http://dx.doi.org/10.1016/ j.taap.2009.07.006.

55. Danylovych IV. [Hydrogen peroxide inhibits acetylcholinesterase of myometrium sarcolemma]. Ukr Biokhim Zh. 2009;81:32-8. Ukrainian.

56. Molochkina EM, Zorina OM, Fatkullina LD, Goloschapov AN, Burlakova EB. H2O2 modifies membrane structure and activity of acetylcholinesterase. Chem Biol Interact. 2005;157-8:401-4, http://dx.doi.org/10.1016/j.cbi.2005. 10.075 .

57. O'Malley BW, Mengel CE, Meriwether WD, Zirkle LG Jr. Inhibition of erythrocyte acetylcholinesterase by peroxides. Biochemistry. 1966;5(1):40-4, http://dx.doi.org/10.1021/bi00 $865 \mathrm{a} 006$.

58. Schallreuter KU, Elwary S. Hydrogen peroxide regulates the cholinergic signal in a concentration dependent manner. Life Sci. 2007;80:2221-6, http://dx.doi.org/10.1016/j.lfs. 2007.01.028.

59. Hildebrandt AG. The binding of metyrapone to cytochrome P-450 and its inhibitory action on liver microsomal mixed-function oxidase reactions. Biochem J. 1971; 125(2):6P-8P.

60. Gonzalez FJ. Role of cytochromes P450 in chemical toxicity and oxidative stress: Studies with CYP2E1. Mutat Res. 2005;569:101-10, http://dx.doi.org/10.1016/j.mrfmmm. 2004.04.021.

61. Zangar RC, Davydov DR, Verma S. Mechanisms that regulate production of reactive oxygen species by cytochrome P450. 
Toxicol Appl Pharmacol. 2004;199:316-31, http://dx.doi. org/10.1016/j.taap.2004.01.018.

62. Łukaszewicz-Hussain A. Subchronic intoxication with chlorfenvinphos, an organophosphate insecticide, affects rat brain antooxidative enzymes and glutathione levels. Food Chem Toxicol. 2008:46:82-6, http://dx.doi.org/10.1016/ j.fct. 2007.06.038.

63. Łukaszewicz-Hussain A. [Liver and serum glutathione concentration and liver hydrogen peroxide in rats subchronically intoxicated with chlorfenvinphos - organophosphate insecticde]. Med Pr. 2011;62:23-9. Polish.
64. Hutson DH, Logan CJ. Detoxification of the organophosphorus insecticide chlorfenvinphos by rat, rabbit and human liver enzymes. Xenobiotica. 1986;16:87-93, http://dx.doi. org/10.3109/00498258609043509.

65. Ikeda T, Tsuda S, Shirasu Y. Pharmacokinetic analysis of protection by an organophosphorus insecticide, chlorfenvinphos, against the toxicity of its succeeding dosage in rats. Fundam Appl Toxicol. 1992;18:299-306, http://dx.doi. org/10.1016/0272-0590(92)90059-Q.

This work is available in Open Access model and licensed under a Creative Commons Attribution-NonCommercial 3.0 Poland License - http://creativecommons.org/ licenses/by-nc/3.0/pl/deed.en. 